\title{
Farmers' Participation in Weekly Organic Bazaars in Aurangabad, India
}

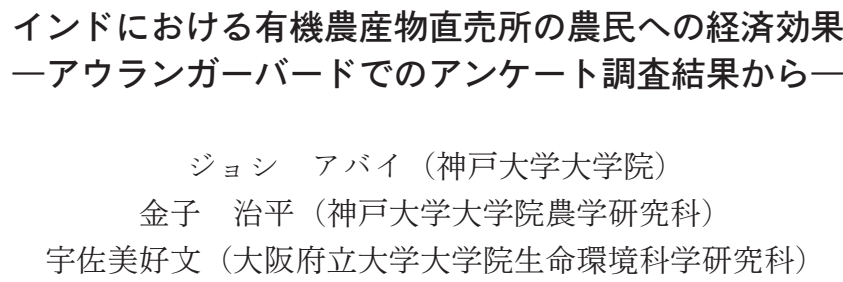

Joshi Abhay (Graduate School of Science and Technology, Kobe University)

Kaneko Jihei (Faculty of Agriculture, Kobe University)

Usami Yoshifumi (Environmental Sciences and Technology, Osaka Prefecture University)

インドで有機農業を発展させるためには，有 機農産物を有利に販売するための流通経路の形 成が必要である。アウランガーバードにある総 合農村開発施設（IIRD）は，NGOとして無償に 近い有機農産物認証制度と有機農産物の農産物 直売所（オーガニック・バザー）を小規模な農 家に提供している。本稿では，オーガニック・ バザーで有機野菜を販売している農家を対象に

\section{Background and purpose}

In 2000, the government of India established the National Programme for Organic Production (NPOP). NPOP set a standard for organic production, system criteria, procedures for accreditation of inspection, certification bodies and the national organic logo with the regulations governing its use. The standard is meant to (but does not) meet the international standard requirements of CODEX and IFOAM. The government created the programme for both the international and domestic markets [1]. In reality, this standard is not for domestic purposes but for export.

When organic farmers want to sell their products as organic, they have to be certified by accredited agencies designated by NPOP. Only organic products grown by certified farmers are allowed to be in markets under the name of "India Organic" . Charges for obtaining this certification vary by accredited agencies, but it usually costs more than Rs. 20,000/year ${ }^{1}$. Large landholding farmers who grow organic processing products like spices, tea and coffee can afford the certification cost. Therefore, a substantial export market for the organic processing products has already been
アンケート調査を行い，オーガニック・バザー が農家に与える影響を検討した。調査結果から， （1）小規模農家を中心に有機野菜の生産が行わ れて拈り，(2) オーガニック・バザーで野菜や スパイスを直売することによって小規模農家の 所得は増加して抎り，（3）有機野菜の生産を増 加させる農家が存在していることが確認された。

well developed in India. In contrast, the cost is unaffordable for small farmers who mainly produce seasonal vegetables for domestic markets. Therefore, domestic markets for organic fruits and vegetables are yet to be developed.

Our previous research has shown that the ecological neem pesticide, which is effective for cultivating spices and vegetables, is mostly used by small and marginal farmers [2]. However, those eco-friendly farmers have to sell their crops with other conventional ones without any price premium since there are few organic markets in the district. If an organic market exists, farmers can sell their organic products on the organic market with a price premium. Their income will increase and thus more farmers will adopt organic farming.

We examine the Institute for Integrated Rural Development (IIRD) located in Aurangabad, Maharashtra State. The organization has a unique marketing channel for organic products, which has increased organic farming Aurangabad had a population of 892,483 in 2001 [3] and is one of the driest areas in Maharashtra State with a temperature range of $9^{\circ} \mathrm{C}$ to $40^{\circ} \mathrm{C}$, and rainfall only occurs in 
the monsoon season from June to September. Average annual rainfall is $725 \mathrm{~mm}$; however rainfall varies within the monsoon season from 9 to $693 \mathrm{~mm} / \mathrm{month}$ [4]. The main crop in Kharif season is cotton.

The following section presents the outlook of IIRD, the organic bazaar and the organic link. The third section presents the effects of the organic bazaar on farmers' income and the price difference between the organic bazaar or the organic link and conventional markets. The fourth section is the conclusion.

\section{IIRD and the organic bazaar}

IIRD was established as a trust in 1987. Its objective is "to promote development alternatives through the initiatives of groups of rural poor" [5]. To accomplish this objective, IIRD has supported the rural development through a Vocational Training Program, and Rural Housing and Support for the Aged. In 2004, IIRD added a Sustainable Organic Agriculture Program (SOAP).

IIRD helps farmers to meet criteria as certified organic farmers for a two-year period. The certification system is a sort of Participatory Organic Guarantee System featured by farmers' mutual inspection [6]. The process is free of charge and therefore affordable for small and marginal farmers. However, this certification is not authorized by NPOP, so farmers are not allowed to use the Organic India logo on their products.

After the farmers' certification has been approved by IIRD, they are provided two market channels to sell their products through the SOAP. One is called the organic link, which is an organic store for organic processed foods and a few seasonal vegetables. The other is the organic bazaar where only organic vegetables and spices are available. This bazaar is held every Friday and located near the Aurangabad station facing the main street. In this study our research focuses solely on organic bazaar.

In the beginning, the organic bazaar was held twice a

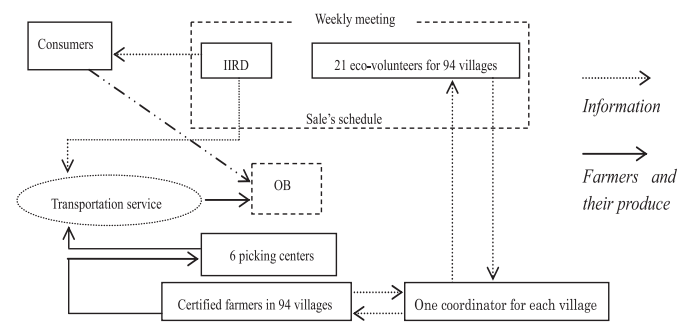

Fig. 1. System of the organic bazaar (OB) operations. week except during the summer. In 2004-2005, the organic bazaar was held 72 times and in 2005-2006 it was held 78 times. Due to the unavailability of a market place, the organic bazaar now takes place on a weekly basis. In 2006-2007 it was held 54 times; in 2007-2008 it was held 53 times. The current market place is rented every Friday by IIRD for the monthly rent of Rs. 1500, but the contract is only temporary. Approximately 20 registered farmers at a time participate in the weekly organic bazaar and sell their products directly to consumers.

According to our interview, consumers are more interested in products being organic than in their actual quality. Incidentally, the registered farmers can sell their organic product with the non-organic conventional products in a wholesale or weekly market (below, we abbreviate them as conventional markets), but their products cannot be sold as organic.

The number of the registered farmers is constantly increasing. There were 596 registered farmers in 2004$2005,1,500$ in 2005-2006, and 2,324 in 2006-2007 ${ }^{2)}$.

At present at IIRD about 2,800 farmers are registered from 94 villages. These villages are divided into seven Community Learning Centers (CLC). In general, 12 to 13 villages come under one CLC and each registered farmer belongs to one CLC.

Farmers who want to sell at the organic bazaar must be certified farmers in 94 villages (Figure 1). The organic bazaar is open from 1:00 pm to 7:00 pm every Friday. Late Tuesday night or early Wednesday morning a registered farmer contacts a coordinator in each village for his interest in selling his products in the upcoming organic bazaar. On Wednesday, eco-volunteers in each CLC have a weekly meeting with the coordinators in which the coordinators inform them how many farmers from each village want to attend the organic bazaar in addition to their product names and the quantity. On Thursday these eco-volunteers gather in the IIRD head office to give information from the weekly meeting and IIRD makes the decisions for the organic bazaar on Friday. This decision includes the number of participant farmers and the variety of products which they want to sell, in order to avoid the unsold product at the end of the organic bazaar. Lastly, the eco-volunteers telephone the coordinators or visit them in person when they return to their villages to inform the farmers of the decision.

There are six picking centers for the farmers to bring their agricultural produce. A truck service transports the 
farmers with their produce to the organic bazaar for free. When the organic bazaar has finished, the truck service returns the farmers to the picking centers. IIRD collects Rs. 30 as a table charge from each participant farmer. On the day of the organic bazaar, four IIRD staff members are sent to observe the bazaar.

On Thursday, a member of the IIRD staff is sent to a market in the city to find out the market prices of the agricultural produce. In general, the price for the organic bazaar agricultural product is set $10 \%$ higher than the market price. On the day of the organic bazaar, a list of product names and prices will be written on a blackboard to prevent haggling; the farmers have the right to sell their produce at or less than the price written on the blackboard. In addition, IIRD has a list of regular customers at the organic bazaar and sends the message by SMS so that the farmers will be able to sell all their produce. The message consists of exact details of the organic bazaar in that week.

We will compare the characteristics of IIRD to that of Teikei ${ }^{5}$. Teikei was formed in order to meet the demand for consumers' safe agricultural products; the organic bazaar started for the purpose of increasing farmers' income. Both Teikei and the organic bazaar have eliminated the middleman from agricultural product marketing. Therefore, if the farmers receive the same price for their products as consumer price through conventional markets, their net income may increase more than that in the markets. As we mentioned above, the organic bazaar price is higher than that in the city's consumer market. The price in Teikei is almost the same as or less than the consumer price in general [7]. In Teikei, consumers have purchased all the agricultural products which the farmers produced. However, farmers in the organic bazaar have to bring home the unsold agricultural products like an agricultural-products outlet in Japan (Chokubaijo).

\section{The organic bazaar effects on farmers' income}

First we will examine the scale of the registered farmers' cultivation, using the data of Tondoli CLC which has about 300 the registered farmers. Table 1 shows the distributions of NSS, BPL census, and the registered farmers of IIRD in Tondoli CLC.

The NSS data is often used in research on the Indian rural economy. But we can obtain only the figures of a Maharashtra State unit, since the NSS data is from a sampling survey. Although we can get the BPL census data for every village, we can get them in bigger classifications. The BPL census data (Table 1) totals only 12 villages in Tondoli CLC. When we see the data of NSS and BPL census, farmers with less than 2.5 acres account for more than $40 \%$ of all farmers. Moreover, farmers with more than five acres account for more than $20 \%$. In other word, farmers with $2-5$ acres account for only about 21 to $36 \%$ in accordance with the data of NSS or BPL census.

We got the size of registered farmers in Tondoli CLC integrally on the document of IIRD. It was written when IIRD registered a farmer. Table 1 shows that very few farmers have one acre or less and that very few farmers have six acres or more, as compared with the data from the NSS or BPL census. This means that farmers with 2-5 acres comprise the largest part of the registered farmers. The feature, that there are very few semimedium or larger registered farmers, is consistent with the purpose of IIRD. However, we have to remember the number of marginal registered farmers is also very small, even though IIRD is meant to assist them.

In order to examine the effect of the organic bazaar, we administered two field surveys to farmers. One survey was completed by farmers who are the registered farmers and who at least once sold their produce in the organic bazaar or the organic link. In the survey we chose the substantial number of farmers from each farm size class because we wanted to examine the different behavior with their farm sizes. We visited and interviewed 96 farmers in their farm lands in July 2009. The other survey was administered to 23 farmers who participated in the organic bazaar on 18 September 2009.

Next, we examine the price in the organic bazaar and conventional market from the survey in July. The prices in the season of Kharif 2008 are calculated from the quantity and the sales amount which are recalled by farmers. Table 2 shows the prices.

The farmers produced grains, agricultural products for processing, and many vegetables. Among all the crops only cotton, soya and sugarcane were sold only in conventional markets. With these exceptions, the prices sold in the organic bazaar and the organic link is higher than in conventional markets. Grain or agricultural products for processing are sold not in the organic bazaar but in the organic link. As the marketing amount in the organic link is much less than the registered farmers produces and the processing cost is required for the marketing in the organic link, the differences in price are not large. 


\section{Table 1. Distribution of operational holdings in Maharashtra and Tondoli CLC and of Registered Farmers in Tondoli CLC}

\begin{tabular}{|c|c|c|c|c|c|c|c|}
\hline \multicolumn{2}{|c|}{ NSS } & \multicolumn{3}{|c|}{ BPL Census } & \multicolumn{3}{|c|}{ Registered Farmers in Tondoli CLC } \\
\hline Size & $\begin{array}{c}\text { Percentage of } \\
\text { number of } \\
\text { operational } \\
\text { holdings } \\
\end{array}$ & Size & $\begin{array}{l}\text { Number of } \\
\text { farmers }\end{array}$ & $\begin{array}{c}\text { Percentage } \\
(\%)\end{array}$ & Size & $\begin{array}{l}\text { Number of } \\
\text { farmers }\end{array}$ & $\begin{array}{c}\text { Percentage } \\
(\%)\end{array}$ \\
\hline \multirow{2}{*}{$\sim 2.5$ acres } & \multirow{2}{*}{$49.5 \%$} & \multirow{2}{*}{$\sim 2.5$ acres } & \multirow{2}{*}{601} & \multirow{2}{*}{$42.9 \%$} & 1 acre & 2 & $0.7 \%$ \\
\hline & & & & & 2 acre & 54 & $18.1 \%$ \\
\hline \multirow{3}{*}{$2.5 \sim 5$ acres } & \multirow{3}{*}{$21.4 \%$} & \multirow{3}{*}{$2.5 \sim 5$ acres } & \multirow{3}{*}{499} & \multirow{3}{*}{$35.6 \%$} & 3 acre & 82 & $27.5 \%$ \\
\hline & & & & & 4 acre & 33 & $11.1 \%$ \\
\hline & & & & & 5 acre & 83 & $27.9 \%$ \\
\hline \multirow{5}{*}{$5 \sim 10$ acres } & \multirow{5}{*}{$19.1 \%$} & \multirow{7}{*}{$\begin{array}{c}5 \sim 12.5 \\
\text { acres }\end{array}$} & \multirow{7}{*}{189} & \multirow{7}{*}{$13.5 \%$} & 6 acre & 13 & $4.4 \%$ \\
\hline & & & & & 7 acre & 6 & $2.0 \%$ \\
\hline & & & & & 8 acre & 3 & $1.0 \%$ \\
\hline & & & & & 9 acre & 5 & $1.7 \%$ \\
\hline & & & & & 10 acre & 11 & $3.7 \%$ \\
\hline \multirow{4}{*}{$\begin{array}{c}10 \sim 20 \\
\text { acres }\end{array}$} & \multirow{4}{*}{$8.8 \%$} & & & & 11 acre & 1 & $0.3 \%$ \\
\hline & & & & & 12 acre & 3 & $1.0 \%$ \\
\hline & & \multirow{3}{*}{12 acres } & \multirow{3}{*}{111} & \multirow{3}{*}{$7.9 \%$} & 13 acre & 2 & $0.7 \%$ \\
\hline & & & & & $14 \sim 20$ acre & 0 & $0.0 \%$ \\
\hline 20 acres & $1.2 \%$ & & & & 20 acre $\sim$ & 0 & $0.0 \%$ \\
\hline Total & $100.0 \%$ & & 1400 & $100.0 \%$ & & 298 & $100.0 \%$ \\
\hline
\end{tabular}

Source: 1) National Sample Organization, Min. of Statistics and Programme Implementation, GOI, Some Aspects of Operational Land Holdings in India, 2002-03, NSS Report 492, 2006.

2) Ministry of Rural Development, BPL Census (http://bpl.nic./in/)

3) IIRD Document (Tondoli CLC)

Note: 1) Aurangabad districts are located in the State of Maharashtra

2) Area of the BPL Census data is limited in the Tondoli CLC which has 12 villages.

However, when we see the leafy vegetables and the other vegetables sold in the organic bazaar, the former are 16 to $241 \%$ higher than conventional markets and the latter are 27 to $142 \%$ higher. In total, with the simple average of their prices by crop types, grain in the organic bazaar and the organic link are about $53 \%$ more expensive than they are in conventional markets, leafy vegetables about $128 \%$ and other vegetables $87 \%$.

The prices of vegetable in the organic bazaar are much higher than that in conventional markets. Though we cannot be certain, we suppose the reasons are as follows. (1) The consumer price through a wholesale market is added an agent commission ( $8 \%$ of their sales amount $)^{3)}$, a wholesaler margin and a retailer margin to the farmer's price. (2) The price in the organic bazaar is $10 \%$ higher than the consumer price in the local market. (3) In the weekly market, farmers sell their produce directly to consumers. However the price in the weekly market would not be as high, because the weekly market is located not in the city area but in the rural area.

IIRD financially supports organic farmers. For example, it provides free the transportation system from the picking points to the organic bazaar and pay for the rent for the location of organic bazaar. Therefore, the registered farmers can increase their income with the price premium. The organic bazaar successfully increases organic farmers' income; however, in another word, their income heavily relies on IIRD's financial support. Therefore, the system of organic bazaar will not be sustained without IIRD.

If the registered farmers selling in the organic bazaar have to bring their unsold products home, it causes a fall in their income. From our survey on 18 September 2008, we found the unsold product is $60 \mathrm{~kg}$ of $656 \mathrm{~kg}$ which the registered farmers brought for the organic bazaar. In addition, according to our interviews with IIRD, the unsold products were about $10 \%$ of what farmers brought in the organic bazaar. Since the price premium is about $100 \%$, the loss is almost negligible and farmers' income rises.

The farmers' participant rate in the organic bazaar varies by size of their farmlands. We show the sales quantity and amount for the organic bazaar and conventional markets by size and by crop type in Table 3 . As most the 
Table 2. Prices in Organic Link or Organic Link and Conventional Markets (Kharif 2008)

\begin{tabular}{|c|c|c|c|c|c|c|c|c|c|c|}
\hline \multirow[b]{2}{*}{$\begin{array}{c}\text { Name of } \\
\text { Crops }\end{array}$} & \multirow[b]{2}{*}{$\begin{array}{c}\text { Name of } \\
\text { Crop }\end{array}$} & \multicolumn{4}{|c|}{ Organic Link or Organic Bazaar } & \multicolumn{4}{|c|}{ Conventional Markets } & \multirow[b]{2}{*}{$(\mathrm{A}) /(\mathrm{B})$} \\
\hline & & $\begin{array}{l}\text { Number } \\
\text { of farmers }\end{array}$ & $\begin{array}{l}\text { Average } \\
\text { Price } \\
\text { (A) } \\
\text { (Rs./Kg) }\end{array}$ & $\begin{array}{l}\text { Minimum } \\
\text { Price } \\
\text { (Rs./Kg) }\end{array}$ & $\begin{array}{l}\text { Maximum } \\
\text { Price } \\
\text { (Rs./Kg) }\end{array}$ & $\begin{array}{c}\text { Number of } \\
\text { farmers }\end{array}$ & $\begin{array}{l}\text { Average } \\
\text { Price } \\
\text { (A) } \\
\text { (Rs./Kg) }\end{array}$ & $\begin{array}{l}\text { Minimum } \\
\text { Price } \\
\text { (Rs./Kg) }\end{array}$ & $\begin{array}{c}\text { Maximum } \\
\text { Price } \\
\text { (Rs./Kg) }\end{array}$ & \\
\hline \multirow{12}{*}{$\begin{array}{r}\text { Grain or } \\
\text { Agricultural } \\
\text { Product for } \\
\text { Processing }\end{array}$} & Sorghum & 2 & 19.2 & 15 & 40 & 14 & 9.2 & 7 & 12 & $209 \%$ \\
\hline & Cotton & & & & & 81 & 26.7 & 25 & 28 & - \\
\hline & Cowpea & 5 & 32.9 & 32 & 40 & 1 & 15.3 & 15 & 16 & $215 \%$ \\
\hline & Kulit & 1 & 30.0 & 30 & 30 & 1 & 22.0 & 22 & 22 & $136 \%$ \\
\hline & Maize & 12 & 9.9 & 8 & 10 & 39 & 8.1 & 6 & 18 & $123 \%$ \\
\hline & $\begin{array}{l}\text { Green } \\
\text { Beans }\end{array}$ & 2 & 35.0 & 30 & 40 & 6 & 22.3 & 25 & 30 & $157 \%$ \\
\hline & Peanuts & 3 & 23.3 & 20 & 30 & 3 & 15.0 & 15 & 20 & $156 \%$ \\
\hline & Pigeon pea & 5 & 30.7 & 28 & 40 & 42 & 27.6 & 20 & 35 & $111 \%$ \\
\hline & \begin{tabular}{|l} 
Sesame \\
\end{tabular} & 1 & 40.0 & 40 & 40 & 2 & 35.0 & 35 & 35 & $114 \%$ \\
\hline & Soya & & & & & 1 & 18.0 & 18 & 18 & - \\
\hline & Sugarcane & & & & & 5 & 11.8 & 10 & 12 & - \\
\hline & Udid & 1 & 40.0 & 40 & 40 & & & & & - \\
\hline \multirow{5}{*}{$\begin{array}{r}\text { Leafy } \\
\text { Vegetables }\end{array}$} & Cabbage & 3 & 19.3 & 16 & 20 & 5 & 16.6 & 10 & 20 & $116 \%$ \\
\hline & Coriander & 6 & 25.0 & 25 & 25 & 4 & 13.7 & 10 & 25 & $183 \%$ \\
\hline & Fenugreek & 6 & 21.1 & 20 & 25 & 3 & 6.2 & 6 & 10 & $341 \%$ \\
\hline & Dill leaves & 2 & 8.0 & 8 & 8 & 5 & 3.6 & 3 & 4 & $222 \%$ \\
\hline & Spinach & 1 & 21.6 & 15 & 25 & 4 & 7.8 & 6 & 10 & $277 \%$ \\
\hline \multirow{12}{*}{$\begin{array}{r}\text { Roots of } \\
\text { Fruits } \\
\text { Vegetables }\end{array}$} & Amaranth & 2 & 32.0 & 32 & 32 & 2 & 23.6 & 20 & 25 & $136 \%$ \\
\hline & $\begin{array}{l}\text { Bitter } \\
\text { gourd }\end{array}$ & 5 & 35.4 & 32 & 40 & 5 & 15.2 & 10 & 16 & $234 \%$ \\
\hline & Brinjal & 18 & 21.8 & 10 & 32 & 17 & 10.8 & 7 & 20 & $201 \%$ \\
\hline & Chili & 15 & 37.5 & 20 & 40 & 19 & 15.5 & 10 & 20 & $242 \%$ \\
\hline & Cucumber & 4 & 20.8 & 15 & 24 & 3 & 10.7 & 10 & 12 & $195 \%$ \\
\hline & Luffa & 3 & 30.9 & 30 & 32 & 2 & 17.6 & 16 & 20 & $176 \%$ \\
\hline & Garlic & 4 & 56.7 & 40 & 60 & 4 & 44.7 & 20 & 60 & $127 \%$ \\
\hline & Gawar & 14 & 32.4 & 30 & 40 & 10 & 18.8 & 15 & 25 & $172 \%$ \\
\hline & Ginger & 2 & 80.0 & 80 & 80 & 7 & 35.7 & 30 & 40 & $224 \%$ \\
\hline & Okra & 9 & 29.6 & 15 & 40 & 17 & 17.0 & 6 & 40 & $174 \%$ \\
\hline & Onion & 4 & 10.2 & 10 & 12 & 8 & 7.7 & 6 & 10 & $134 \%$ \\
\hline & Tomato & 7 & 31.2 & 30 & 32 & 9 & 13.8 & 10 & 20 & $227 \%$ \\
\hline
\end{tabular}

Source: Our field survey in July 2009.

registered farmers have $2-5$ acres, we classified a farmer of $1.5-5$ acre as a small farmer.

The marginal farmers grew crops like cotton and didn't grow any vegetables except for home use. They earn a stable income from cotton as a target crop of the Minimum Price Support (MSP) in India and received 97\% of their income from conventional market. On the other hand, the price of vegetables is unstable.

The small farmers are main vegetable growers for the organic bazaar. In average, they grew vegetables using about one third of their land and sold more than half of vegetables for the organic bazaar, which amounts to $23 \%$ of their income. It is because they need regular and frequent income cash from their limited land; the organic bazaar held on weekly basis, so they can obtain income cash every week. In contrast, the semi-medium and larger farmers used most of their land for grain and cotton because of their limited family labor and large land and they tend to sell on the conventional market even if they grow vegetables and spices ${ }^{4)}$.

Farmers who want to sell in the organic bazaar have to bring more than one vegetable because they will reduce the unsold products. Though the semi-medium and larger farmers used almost the same amount of land as the small farmers, the number of crops by the former is $1.4-1.8$, and that by the latter is 2.2 in average. Therefore the cropping pattern of small farmers is better suited to the organic bazaar. 


\section{Table 3. Production and its sales amount in $\mathrm{OB}$ and conventional markets by size and by crop type (Kharif 2008)}

\begin{tabular}{|c|c|c|c|c|c|c|c|c|c|c|c|c|c|c|c|c|}
\hline \multirow{3}{*}{$\begin{array}{c}\text { Cultivating } \\
\text { Area in Kharif } \\
2008\end{array}$} & \multirow{3}{*}{$\left|\begin{array}{c}\text { Number } \\
\text { of } \\
\text { Farmers }\end{array}\right|$} & \multicolumn{7}{|c|}{ Grain or Agricultural Product for Processing } & \multicolumn{7}{|c|}{ Vegetables } & \multirow{3}{*}{$\begin{array}{c}\text { Total } \\
\text { Income } \\
\text { (Rs) }\end{array}$} \\
\hline & & \multirow{2}{*}{$\begin{array}{c}\text { Number of } \\
\text { Crops }\end{array}$} & \multirow{2}{*}{$\begin{array}{l}\text { Acre of } \\
\text { Land } \\
\text { (acre) }\end{array}$} & \multirow{2}{*}{$\begin{array}{c}\text { Total } \\
\text { Production } \\
(\mathrm{kg})\end{array}$} & \multicolumn{2}{|c|}{$\begin{array}{c}\text { Organic Link or } \\
\text { Organic Bazaar }\end{array}$} & \multicolumn{2}{|c|}{$\begin{array}{c}\text { Conventional } \\
\text { markets }\end{array}$} & \multirow{2}{*}{$\begin{array}{c}\text { Number } \\
\text { of } \\
\text { Crops }\end{array}$} & \multirow{2}{*}{$\begin{array}{c}\text { Acre of } \\
\text { Land } \\
\text { (acre) }\end{array}$} & \multirow{2}{*}{$\begin{array}{c}\text { Total } \\
\text { Production } \\
(\mathrm{kg})\end{array}$} & \multicolumn{2}{|c|}{$\begin{array}{l}\text { Organic Link or } \\
\text { Organic Bazaar }\end{array}$} & \multicolumn{2}{|c|}{$\begin{array}{c}\text { Conventional } \\
\text { markets }\end{array}$} & \\
\hline & & & & & $\begin{array}{c}\text { Sales } \\
\text { Quantity } \\
(\mathrm{kg})\end{array}$ & $\begin{array}{c}\text { Sales } \\
\text { Amount } \\
(\mathrm{Rs})\end{array}$ & \begin{tabular}{|c|} 
Sales \\
Quantity \\
(kg)
\end{tabular} & \begin{tabular}{|c} 
Sales \\
Amount \\
$(\mathrm{Rs})$
\end{tabular} & & & & \begin{tabular}{|c|} 
Sales \\
Quantity \\
$(\mathrm{kg})$
\end{tabular} & \begin{tabular}{|c|} 
Sales \\
Amount \\
(Rs)
\end{tabular} & $\begin{array}{c}\text { Sales } \\
\text { Quantity } \\
(\mathrm{kg})\end{array}$ & $\begin{array}{c}\text { Sales } \\
\text { Amount } \\
\text { (Rs) }\end{array}$ & \\
\hline $\begin{array}{c}\text { Marginal } \\
(\sim 1.5 \text { acre })\end{array}$ & 5 & 1.6 & 1.4 & 1,930 & 80 & $\begin{array}{r}800 \\
(2.8 \%) \\
\end{array}$ & 1,840 & $\begin{array}{r}27,960 \\
(97.2 \%) \\
\end{array}$ & 0.0 & 0.0 & 0 & 0 & $\begin{array}{r}0 \\
(0.0 \%) \\
\end{array}$ & 0 & $\begin{array}{r}0 \\
(0.0 \%) \\
\end{array}$ & $\begin{array}{r}28,760 \\
(100.0 \%)\end{array}$ \\
\hline $\begin{array}{c}\text { Semimedium } \\
(5 \sim 10 \text { acre })\end{array}$ & 31 & 3.0 & 6.1 & 6,443 & 92 & $\begin{array}{r}1,629 \\
(1.3 \%) \\
\end{array}$ & 6,026 & $\begin{array}{l}109,485 \\
(85.8 \%) \\
\end{array}$ & 1.8 & 1.2 & 1,018 & 265 & $\begin{array}{r}6,443 \\
(5.0 \%) \\
\end{array}$ & 691 & $\begin{array}{l}10,086 \\
(7.9 \%)\end{array}$ & $\begin{array}{r}127.643 \\
(100.0 \%) \\
\end{array}$ \\
\hline $\begin{array}{c}\text { Medium or } \\
\text { Large } \\
(10 \text { acre } \sim)\end{array}$ & 9 & 3.6 & 14.6 & 10,683 & 22 & $\begin{array}{r}778 \\
(0.4 \%)\end{array}$ & 10,461 & $\begin{array}{l}191,372 \\
(88.7 \%)\end{array}$ & 1.4 & 1.0 & 799 & 123 & $\begin{array}{r}3,033 \\
(1.4 \%)\end{array}$ & 633 & $\begin{array}{l}20,500 \\
(9.5 \%)\end{array}$ & $\begin{array}{r}215,713 \\
(100.0 \%)\end{array}$ \\
\hline
\end{tabular}

Source: Our field survey in July 2009.

Note: Total production in cludes home use.

As mentioned above, mainly the small farmers can benefit from the organic bazaar. Therefore some farmers changed their cropping pattern for the organic bazaar as the acre of land affect the total income of the farmers. For example, a farmer with four acres grew only cotton in Kharif 2004, and switched to cabbage on 0.5 acre, chili on 1 acre, onions on 1 acre, corn on 0.5 acre and pigeon peas on 1 acre in Kharif 2008. We could find seven farmers who had increased their share of vegetable land among eight farmers whom we could match between our survey and the IIRD document when IIRD registered them.

\section{Conclusion}

IIRD implemented a rural development program and a certification system for organic farming by providing selling opportunities, such as organic bazaar. Previously, the farmers had no choice but selling their products to a wholesale market. However, due to IIRD's support, certification fees became virtually free, and the organic bazaar was held as an alternative marketing channel. Therefore, farmers increasingly changed their cropping pattern to organic and grew vegetables and spices instead of cotton. As a result, organic farming is increasingly popular among farmers.

According to our survey, farmers' income rose significantly because of their direct selling in the organic bazaar. Thus the organic bazaar increased farmers' income and heightened their interest in organic farming. If a farmer can grow more profitable crops more easily, farmers are encouraged to grow more of those crops [8].

In light of changes in consumers' awareness of the income change that accompanies economic growth, the organic bazaar will be the germ of new development, or the frontier of organic marketing channel in India's domestic agricultural market.

\section{Acknowledgements}

The authors are very grateful to Mr. Joy Daniel, The IIRD managing trustee and staff members for their support during our stay in Aurangabad. We are very thankful to each farmer in Aurangabad for their great cooperation with our fieldwork.

Note

1) Authors' telephone survey to accredited agencies in India.

2) J. Daniel from IIRD, personal communication in September 2009.

3) Interview with farmers in the wholesale market in Aurangabad in July 2008.

4) Though small and semi-medium farmers sold their vegetables with higher price in the organic bazaar than in conventional markets, medium and larger farmers sold their vegetables at higher prices in conventional markets than in the organic bazaar. This fact does not show that medium and larger farmers can sell their produce at high prices in conventional markets. It shows that they grow ginger, which is very expensive.

5) Teikei is Japanese type community supported agriculture to link between producers and consumers who encourage local level organic farming. 


\section{Reference}

[1] National Programme For Organic Production. Department of Commerce. Ministry of commerce \& Industry. New Delhi. Sixth edition: May 2005.

[2] Joshi, Usami and Kaneko 2009. Economics of Neem Pesticide Application: A Case Study in Nagpur and Wardha, India. Journal of Rural Problems 175: 45.

[3] http://www.censusindia.gov.in

[4] http://en.wikipedia.org/wiki/Aurangabad,_Maharas
htra\#Population_trends (November $10^{\text {th }} 2009$ )

[5] http://www.iird.org.in/ (2009)

[6] Khosla R.- A Participatory Organic Guarantee System for India (2006). http://www.ifoam.org

[7] Takeshi Hatano, "Economics of Organic Farming" (1997), Nihonkeizaihyoron, Japan.

[8] Theodore W. Schultz, "Transforming Traditional Agriculture” (Study in Comparative Economics), 1964, Yale University Press. 